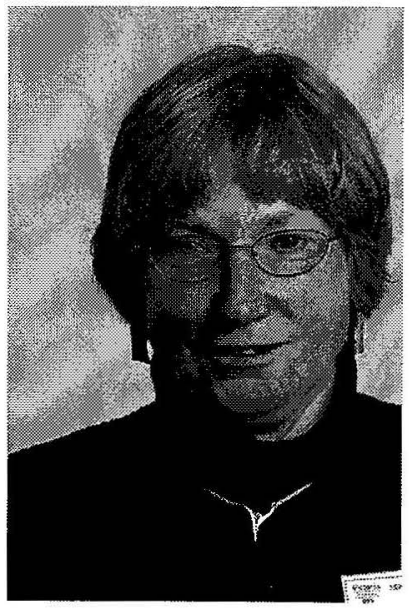

\title{
COMPLIANCE AS RESISTANCE TO NORMATIVE CONTROL: EVIDENCE FROM THE CORPORATISATION OF SCIENCE IN NEW ZEALAND
}

\author{
Lesley Hunt \\ Environment, Society and Design \\ Division \\ Lincoln University
}

\begin{abstract}
When the New Zealand Government restructured the system of the public funding of research (1990-1992) it created Crown Research Institutes (CRIs) as companies operating in a global, market-led economy. One CRI, YCo ${ }^{1}$, responded to this environment by corporatisation and instituted a normative system of control of workers which, through strategic plans, vision and mission statements, and performance assessment processes, encouraged workers to adhere to company goals. This paper, reporting on an ethnographic study of this CRI, shows how most scientific workers (technical staff and scientists alike) experienced insecurity through estrangement because the contributions they wished to make were less valued both in society and in their work organisation. They were excluded from participation in both organisational and Government policy-making, and felt they did not 'belong' anymore. Scientists in particular were also experiencing alienation (in the Marxist sense), as they were losing autonomy over the production of their work and its end use. Scientific workers developed tactics in order to resist these experiences and ostensibly comply with organisational goals while maintaining and protecting their self-identities, and making their work meaningful. Meanwhile the work of the CRI continued.
\end{abstract}

\section{Context}

It's actually quite good because $99 \%$ of the people in $\mathrm{YCo}$ hate $\mathrm{YCo}$ - meaning hate corporate - can't see any sense in what's going on. It's not just YCo. It's basically all the CRIs. You see any scientists in New Zealand and they'll bitch about their organisations. It's a great way to start a conversation! It's good because with the new corporate image we are supposed to talk about loyalty and loyalty isn't generated - you don't demand it - it's earned. And no-one's been around [long enough] to have earned anything. And they won't be. They will be gone in 5 years. (Wade, scientist)

In 1999-2000 I was an observer-participant in an ethnographic study of one of New Zealand's Crown Research Institutes (CRIs). I wanted to find out why most scientific workers I came across in the organisation complained about their employer but at the same time were quite clear about how much they loved their work, and how important they felt it was.

The CRIs were formed in 1992, towards the end of the New Zealand Government's restructuring of the public sector which separated the policy provision, funder and provider roles of public sector organisations to ensure greater efficiency in the use of public money and greater accountability to Government policy. To this end CRIs were established as companies to service the research needs of various sectors. CRIs were to receive funding through a competitive bidding system drawn up by the Foundation for Research Science and Technology (FRST) in line with Government priorities as set out by the Ministry of Research Science and Technology (MoRST). These CRIs were free to seek commercial funding in the international and local markets, and many sought to enhance their profitability by the sale or licensing of products and processes and through the protection of intellectual property (IP).

The job of a scientist is to find money Do Science? Ha, ha, don't be funny!

We write lots of proposals

\footnotetext{
${ }^{1}$ The organisation in which this research was carried out has been given a pseudonym, as have any quoted participants in the study.
} 
That end up in garbage disposals

Well, except those that may create a GE bunny

(Limerick competition to celebrate YCo's tenth birthday, 17-7-02)

In the period of their existence the CRIs have been subject to many changes as Government policy has continually modified the role of science. The most recent versions have stressed the importance of research and development in developing a knowledge society, and Government see this as the way New Zealand must move in order to survive in a global economy. Government has also emphasised that less attention is to be paid to commodity production and more to potentially new and innovative industries: “... wealth is increasingly taking the form of knowledge rather than stuff" (Hodgson, 2000: $1-2)$.

\section{Enforcing Corporatisation: The Use of Normative Control}

Edwards (1979: 1-22) saw systems of work control developing through stages as workers resisted control and employers countered resistance. Initially, only hierarchical control was needed but as workplaces grew and technology became more complex, there was the need for technical control, and for bureaucratic control in the form of rules and policies. These have been called external controls. In such systems "the hands matter, but the head and heart do not" (Ashforth and Mael , 1998: 92). Incorporating internal control or self-discipline in workers would decrease costs of supervision, and hence increase global competitiveness and efficiency (Clegg, 1994: 282). This 'internal' system of work control has become known as 'normative' control.

YCo responded to the environment described above, by corporatisation and the use of a system of normative control, which has induced new struggles between individuals and structures, impacting on how individuals make work meaningful, and on who they are, their selfidentity.

A normative control system encourages workers to believe in and practice the direction and goals of their work organisation as espoused by its Board and management through the strategic plan and the mission, vision and value statements. It implies that workers should replace their own meanings with those of the organisation, where these are not consonant. A worker able to commit to these values supposedly will feel as if they belong and become a productive member of the organisation. ${ }^{2}$ If they do not then they will need to be coerced into commitment by such organisational structures as the performance assessment process. For scientific staff, such slavish loyalty is not part of who they are. They have been trained to consider information

\footnotetext{
${ }^{2}$ Willmott (1993) called his paper on this subject 'Strength is Ignorance; Slavery is Freedom: Managing Culture in Modern Organizations'.
}

sceptically as part of their scientific indoctrination and not to trust something they cannot empirically examine. Another obvious challenge to this notion of normative control is its implication of stability and security. In practice the direction and organisational description can change as the organisation itself struggles to survive in a constantly changing environment and this inferred promise of security cannot be realised.

Who or what decides what work means to those who do it? YCo's management have decided that this is its role. As Knights and Willmott (1999: 94) state "defining reality for others is an exercise of power". There is no evidence that workers in YCo did not have high commitment in the past so what has changed now? The commitment required in the past - to science, to agriculture, to the good of New Zealand society by supporting farmers etc. - has been replaced by a demand for commitment to the company (Smith and Thompson, 1999: 207), to products, and to making a profit.

As a result, employees are not feeling valued in their workplace and in society and they feel insecure. They feel as if they no longer fit and their contribution is no longer wanted, either in society as espoused by Government policy or in their work organisation. In other words, scientific staff are experiencing estrangement. They resist this by trying to protect their sense of self-identity found in the places, communities and groups and in doing the things that enhance their awareness of being valued. Scientists are also experiencing alienation (in the Marxist sense) from the products of their work as their former autonomy over it is challenged by policies which place an emphasis on commercial ownership of their IP, and innovative products and processes, above commitments to scientific knowledge, protection of the environment, or the agricultural sector. The latter interests are of major importance to their sense of identity and their perception of the contribution their work makes to society. How scientific workers attempt to overcome these feelings of estrangement and alienation, and continue to make their work meaningful, is pursued in this paper.

\section{Compliance: Survival by Resisting Estrangement and Alienation}

I consider that most scientific workers in $\mathrm{YCo}$ in the groups studied have developed ways of complying that enable them to resist the feelings of estrangement and alienation that they have experienced. Given that exit is not a viable option, they can resist these feelings directly by open challenge, indirectly through compliance by getting on with their work in their own ways, or they can become committed to corporatisation so that they no longer feel estranged or alienated. (This process is summarised in Figure1.) I suggest that these workers are responding to a complex mix. There is no direct and discrete relationship linking scientific workers' responses to the system of normative control put in place by YCo's corporate management. Some are responding as well to Government policy with its emphasis on global economics and commercialisation. These are arenas in 
which workers feel powerless. No-one feels they have power over what is happening at a global level. At the Government level, scientific workers have been shut out of the policy making process ${ }^{3}$ Therefore, the focus of their discontent becomes their work organisation. This reification was very apparent in responses to my interview questions. The 'blame' for workers unhappiness was almost always perceived as the 'fault' of the organisation (or the CEO), not the YCo Board, FRST, MoRST or the Government.

The [YCo] corporate dudes

Got in one of their dangerous moods

They said, "We must keep

Our staff herded like sheep."

Now we all have ID tags like ewes

(Limerick contest to celebrate YCo's tenth birthday, 17-7-02)

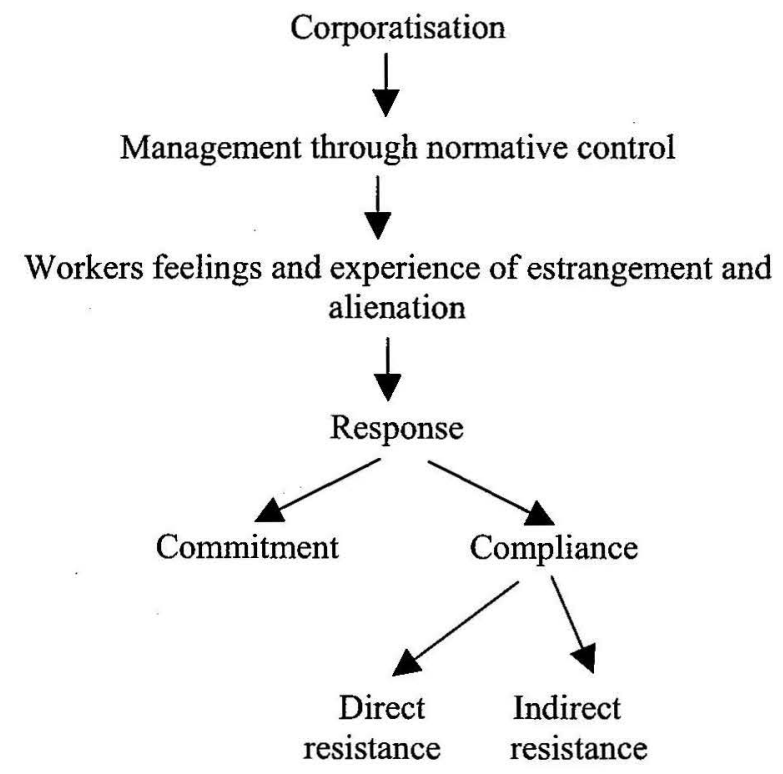

Figure 1: Response of scientific workers to corporatisation

The word compliance implies the existence of an exchange relationship (Kelman, 1958). I construe compliance at work to involve workers making a practice of conforming to what an organisation wants in order to carry out their work. Compliance does not mean that a worker has to 'embrace' the identity offered, but that they conform in order to do something more important to them - something that balances out or rewards them more than the cost of conformity. Compliance implies trying to make work meaningful in such a way that a worker does not experience estrangement even though its causes still exist. Compliance is a way of fighting the possibility of alienation from one's work, by manipulating the work system in a way that enables a worker to have some

\footnotetext{
${ }^{3}$ RSNZ CEO, Steve Thompson, at a meeting of the Canterbury Branch of the Royal Society, $1^{\text {st }}$ March 2002, University of Canterbury, on the topic 'Why trust a scientist?' Also Lancashire (2002) and ACRI (2002).
}

control over what they do at work, and the rewards that work brings.

At first I was puzzled by how these workers could play the games they do while still maintaining their integrity as people and as scientific workers. I was aware of the many distancing tactics they used in order to separate themselves from the things they perceived as possibly influencing who they were and the meanings they had for the work they did. Then I became aware that they were distancing themselves from the ethical challenge to their integrity posed by what they had to do in order to actually carry on in their work in a manner that was meaningful to them. This involved the appropriation of the work, time and resources provided by the funding of their scientific programmes. Hence, this behaviour was a means of resisting the appropriation of their identities by their employer (Ackroyd and Thompson, 1999).

If scientific workers do their work for the 'wrong' reasons, then they are maintaining some control over it stamping their own identity on it unknown to management. When I asked Owen, a scientist, about how he resisted the things he disliked about YCo he tapped his head. What goes on in his head is what is most important and that cannot be touched or influenced.

\section{The Nature of Resistance}

The influence of Marxism is apparent in the many work studies, which till recent times, focused on the so-called working class with attention being paid to factory work and coalmining, for example, because at the time (early 1970s) workers in these industries went on strike for long periods. Marxist supporters always hoped such strikes were indicators of the revolution to come (Rose, 1978: 217). Labour Process Theory (LPT) is based on the dialectic between capital and labour, in which capital is trying to control labour in order to produce more profit, and in which labour resists (Ackroyd and Thompson, 1999: 20, 47; Edwards, 1979; Smith and Thompson, 1999: 211). The second wave of LPT (e.g. Edwards, 1979) described a new labour process which was "not so attached to revolutionary ideas" and class. Resistance was now against management and how it controlled work (Ackroyd and Thompson, 1999: 47) and this has led some writers to focus on white-collar work (e.g. Smith et al, 1996).

\section{Ashforth and Mael (1998: 90) define resistance as:}

... intentional acts of commission or omission that defy the wishes of others. The term intentional signifies that one's motive is central to the dynamics of resistance but does not mean that resistance is necessarily premeditated or rational ... The notion of resistance implies opposition against something, usually the exercise of power - the attempt to influence or control the resister. It is somewhat arbitrary, however, to label one behavior an act of power or control and another as an act of resistance ... 
power and resistance are embedded in a dynamic relationship that tends to be mutually reinforcing ... Acts of control are usually intended to create and maintain the conditions of employment and to craft meaning for organizational members. Conversely, employee responses that are intended to oppose these acts are referred to as resistance. 4

The negative view of resistance as something to be overcome in the workplace is linked, according to Nord and Jermier (1994: 2-3), to the use of the word in psychoanalytic theory where resistance was seen as a denial of reality (as perceived by the therapist). On the other hand, resistance could be how individuals protect themselves from something that could harm them, and so it could be perceived as good and a natural part of change (Klein, 1976). As far as Nord and Jermier are concerned, resistance should be treated as a neutral concept.

The idea of organisational misbehaviour as outlined by Ackroyd and Thompson (1999) is a fascinating and useful one. They adopt Sprouse's (1992: 3) working definition of misbehaviour as "anything you do at work you are not supposed to do". Misbehaviour has a contingent nature related to its context. In contrast to Ackroyd and Thompson's definition, I suggest that those doing the misbehaving could also define misbehaviour. If you see yourself as a cynic and a resistor, then this is how you define your behaviour, management's inattention to it notwithstanding. (Clegg (1994: 296-7) reinforces that self-consciousness has to be part of a worker's selfawareness for certain behaviour to be called resistance.)

This campus has always had a degree of independence and stroppiness inside [YCo]. We were the $\mathrm{DSIR}^{5}$ people. We were always seen as being more cynical. We were not seen as having quite the right culture (Bill, scientist).

Ashforth and Mael (1998: 92) emphasise "the power of resistance lies at least partly in its potential to contest meaning, specifically the definition of the individual derived from organizational membership". It is difficult to describe resistance because as Collinson (1994) indicates, it may contain elements of consent and vice versa. Resistance can serve several purposes simultaneously, the main one of which may be symbolic (Ashforth and Mael, 1998: 102-3). The fact that someone resists can be of far more importance than what happens as a result of such resistance. Self-awareness is something we usually keep secret from others, but it allows us to maintain our own identities without 'rocking the boat' or actually acting it out (Cohen and Taylor, 1992). Much literature has assumed that managerial systems have become so powerful that resistance to them is not really

\footnotetext{
${ }^{4}$ Italics are those of the authors.

${ }^{5}$ DSIR (Department of Scientific and Industrial Research). Staff from DSIR were moved into the CRIs at the time of restructuring.
}

possible (e.g. Clegg, 1994, 1990, 19896 Rose, 1988; Casey, 1995).

\section{Typologies of Resistance}

I have selected four attempts by other writers to develop typologies of resistance or ways of classifying worker behaviour. I use these later to develop different ways of looking at compliance. (These are partial descriptions because I only focus on concepts which resonate with my observations.)

\section{Hodson's Basic Agendas of Resistance}

Hodson (1995) devised four "basic agendas of resistance: deflecting abuse, regulating the amount and the intensity of work, defending autonomy and expanding worker control through worker participation schemes" (Hodson, 1995: 79). (For a simplified schematic diagram see Figure 2.) Hodson relates each of these to four systems of work control as the most likely forms of resistance under such regimes: direct control, technical control (e.g. Taylorism), bureaucratic control, and modern participative ways of organising work.

\section{Workers resist}

$$
\text { labour control }
$$

by

- deflecting abuse
- regulating work
- defending autonomy
- manipulating participation

\section{Figure 2: Hodson's conceptual model of worker} resistance (1995)

Within each 'agenda of resistance' Hodson develops different 'categories'. For example, the 'alternative value systems' category within the 'deflecting abuse' agenda is described as a symbolic rejection of "the definition of the situation provided by those in power" (ibid: 84 ). Such efforts to "delegitimate management" are considered to be a "first crucial step in worker resistance"7 and such "meanings require social affirmation for their continued vitality" (ibid). Crozier (1964) further developed March and Simon's idea of 'bounded rationality ${ }^{8}$ as he saw

\footnotetext{
${ }^{6}$ Collinson (1994: 59) criticises Clegg for his lack of mention of resistance in his 1990 book Modern Organizations, his emphasis on outflanking at the expense of resistance in his 1989 book Frameworks of Power.

${ }^{7}$ Gouldner, 1954; Nichols and Beynon, 1977: 137; Tilly, 1978.

8 Rose (1988: 370) implies that this idea of 'bounded rationality' comes from Crozier, but Crozier indicates the source to be March and Simon's (1958) book Organizations.
} 
there were factors in the workplace that limited rationality (ibid: 150). That is, different groups in the workplace could have 'rationalities' that worked for them but made no sense outside of the group.

Hodson (1995: 95) sees autonomy as being protected when workers take pride in their work and that this is a form of resistance. While Ackroyd and Thompson (1999: 7) say that the main reason people 'misbehave' is to protect and assert their autonomy, they do not look at any 'positive' behaviour in this light.'

\section{Clegg's Strategies of Outflanking}

Clegg (1994) suggests that before a person can become a resistant subject they must first pass through a development of consciousness or awareness of the need for resistance. This requires an explanation of "resistance as a form of power ... in its absence, or at least its minimization" (ibid: 289). This led to his development of what he calls 'strategies of outflanking' - the strategies employers can use to overcome resistance or the potential for resistance. (See Figure 3.) Baumann's (2000: 33-34) description of Crozier's (1964) work as being about how power is gained by those groups who manage to make other groups insecure or uncertain, particularly in state bureaucracies, could also be describing a strategy of outflanking.

Workers cannot resist normative control because they are

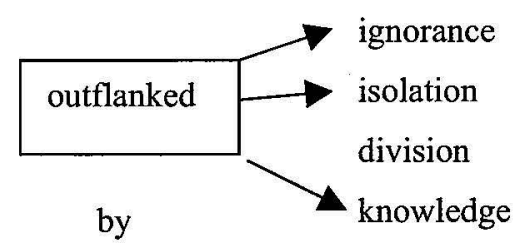

the power of employer in employerworker relationship and how it constitutes worker subjectivity

Figure 3: Clegg's model of how organisations outflank resistance (1994)

Clegg's first description within this concept is simply 'ignorance'. Ignorance can both facilitate or restrict power depending on the context (Clegg, 1994: 289), as people may simply be unaware of alternative ways of seeing something or that networks and ways of linking with people both organisationally or nationally to support their resistance do exist. Another way of thinking of ignorance is that silence may also be indicative of having

\footnotetext{
${ }^{9}$ I use the word 'positive' to describe behaviour which could be seen from one perspective as compliance or identification with company values. Ackroyd and Thompson (1999) are concerned with negative behaviour - behaviour that will not increase production or make more profit for the 'owners'/Capital.
}

no language to articulate a problem. The so-called, 'objective' nature of science and the male dominance of science (Harding, 1992; Fox, 1995; Keller, 1990, 1995; Kirkup and Keller, 1992; Schiebinger, 1999; Zuckerman and Cole, 1991), and the male dominance in organisations like YCo with its primary industry emphasis, do not provide an environment with a language in which emotions and feelings can be expressed.

Clegg (1994: 291) posits that "a further step from isolation is division" in which one's life is compartmentalised in such a way that what goes on in one area stays unrelated to the rest. He claims that the development of instrumentalism could be a form of resistance: "The individual's self-organization may be constructed in terms of divided life-worlds in which one manages the trials and tribulations of relative powerlessness in one sphere by hermetically sealing experience in situational specificity. Subject compartmentalization into segmented and thus psychically protected spheres is a form of resistance in itself, as witness the 'instrumental' worker (Goldthorpe et al, 1969)."

\section{Ackroyd and Thompson's Dimensions of Misbehaviour}

Employees and employers disagree over

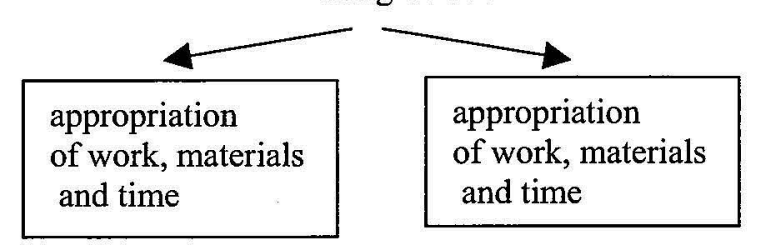

with varying intensities

to

protect autonomy

\section{Figure 4: Ackroyd and Thompson's dimensions of misbehaviour (1999)}

Ackroyd and Thompson (1999: 25) have formed a model involving two axes as 'dimensions of misbehaviour'. (See Figure 4.) The horizontal axis covers four nominal, but not exclusive, areas of contention ("four directions that misbehaviour can take") to do with disagreement over the appropriation of time, work, product (materials used in the work - not 'end product') and identity, with the appropriation of identity being fundamental to all other forms of misbehaviour. The authors define this as the "disagreement over the extent to which employees identify with their work activity and employers" (ibid: $25)$. The ordinal vertical axis covers the degree or 
intensity of the disagreement from positive commitment to hostility. ${ }^{10}$

\section{Assertions of Identity}

Cohen and Taylor's book Escape Attempts: The Theory and Practice of Resistance to Everyday Life (1992) links resistance to the establishment and maintenance of identity. (See also Ashforth and Mael, 1998: 99.) The authors reflect on how, through our propensity for selfconsciousness, we can manage our lives by using distancing tactics (ibid: 52-59). Collinson (1994: 25) transfers this thinking to the workplace to describe how 'resistance through distance' is "the way in which subordinates try to escape or avoid the demands of authority and to 'distance' themselves, either physically of symbolically, from the organization and its prevailing power structure". (See Figure 5.) In the resistance models outlined earlier, Hodson's categories within the 'deflecting abuse' and 'defending autonomy' agendas, and Clegg's 'outflanking' (see later) describe different distancing tactics.

\section{Workers resist}

to

avoid the demands of authority

by

use of distancing techniques

that - deny involvement in

organisational processes

in order to

- maximise economic return

- promote a class identity that is separate from management

Figure 5: Collinson's distancing model for resistance (1994)

If we can make these mental journeys above the petty arrangements of work, marriage and leisure, what need have we to physically distance ourselves from them? We need not change the patterns, but only the way we think about them (Cohen and Taylor, 1992: 53).

As Simmel (1971: 335) said, "For only whoever stands outside his boundary in some sense knows that he stands within it, that is, knows it as a boundary."

\section{Constructing Models of Compliance}

\footnotetext{
${ }^{10}$ This axis, commitment through to hostility, does not make much sense because it is actually connected to only one component of the other axis - work and the employer - not to disagreement over appropriation of time, work and product.
}

Bringing together my observations, reflections and the thoughts of various writers on resistance and its related concepts, I have constructed two pathways which scientific workers may follow in order to be able to comply sufficiently to do their work and for their employing organisation to continue. I indicate that scientific workers are all resisting estrangement but only some, particularly scientists, are resisting alienation hence the two models. In order to make clear whose ideas contributed to my model and which parts are unique to me, the reader will need to refer to the simplified versions of the ideas I have taken from different exponents on resistance (Figures $2-5$ ).

I have used Ashforth and Mael's (1998) idea that resistance is about 'sustaining valued identities'. But how do workers do this? The distancing concept of Collinson (1994) and others before him (e.g. Goffman, 1961; Cohen and Taylor, 1992), and the outflanking concept of Clegg $(1989,1990,1994)$, describe the way workers resist the appropriation of identity by their work or employer (Ackroyd and Thompson, 1999). Whereas Ackroyd and Thompson imply that the appropriation of identity, and hence the threat to autonomy, is resisted by workers' appropriation of resources, time and materials, I say that workers have to distance themselves from the act of appropriation of work, time and materials/resources in order to protect their integrity, resist emotional involvement with an organisation that cannot promise them security, and get on with doing 'their science' for their own reasons. They do not wish to practice these distancing techniques. They would rather just get on with their work of science without being compromised, but that is not possible in an environment of normative control unless they give up their reasons for doing their work and become committed to the organisational goals. Therefore, I have used Ackroyd and Thompson's (1999) idea of appropriation of resources, time and materials, as the means by which scientific workers get to 'do science' and so satisfy their reasons for doing such work, and protecting an important part of their identities. I do not bracket together resistance to the appropriation of identity by the 'employer and work' as Ackroyd and Thompson do. In this context, work is very much part of the identity of workers and is not resisted as such. (There are signs of resistance to this domination of identity by work developing as more instrumentalist attitudes appear among some scientists. This attitude is included as a distancing tactic.)

The appropriation of resources, time and materials is usually associated with doing less work or work that is not related to the employing organisation. In this context I am talking of scientific workers doing 'more work'. Their aim is to 'do science'.

I have used many of the ideas from Hodson (1995) and Clegg (1994) about how workers distance themselves from organisational goals in order to achieve their own. However, Clegg developed his concept of 'outflanking', to describe how organisations actually stop resistance from occurring. I use his concept to describe how workers resist organisational control. So, I turn Clegg's ideas 
around. I also use Hodson's categories as descriptions of resistance rather than control.

\section{Compliance by Resisting Estrangement}

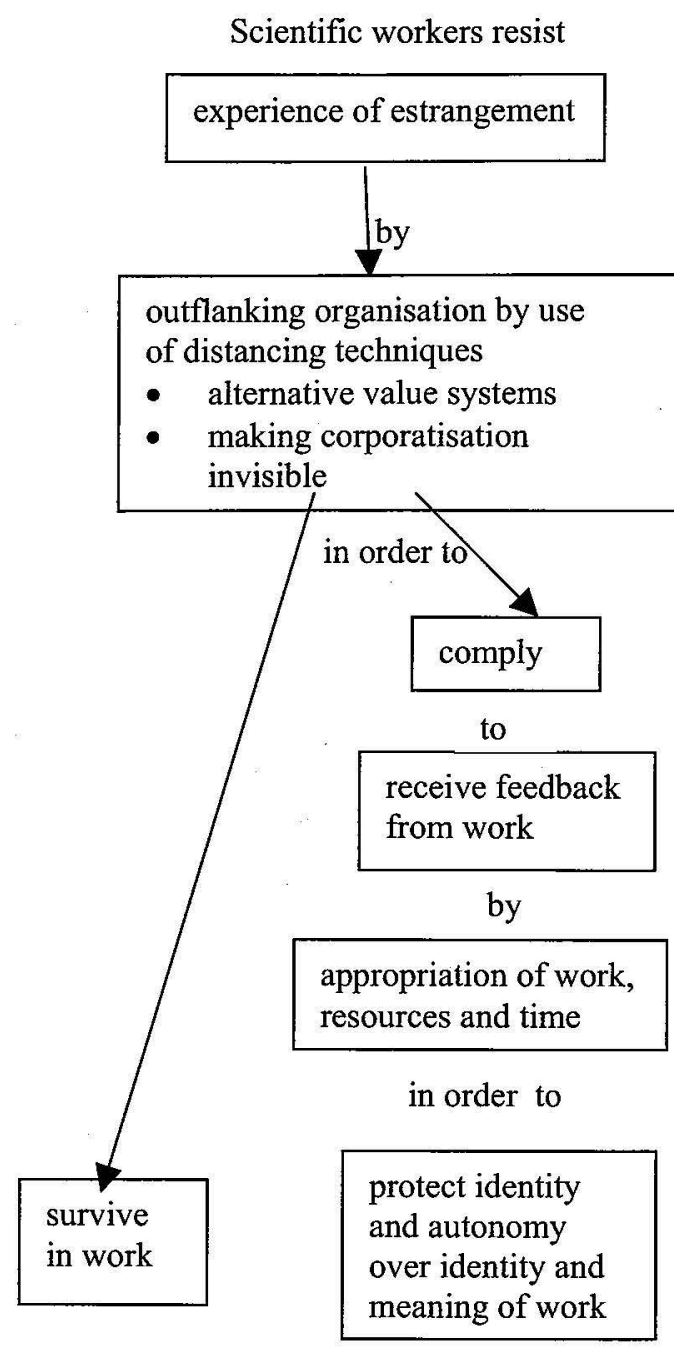

Figure 6: Model of how scientific workers try to resist estrangement in a system of normative control

My model (Figure 6) articulates that in order to comply, scientific workers 'outflank' the organisation by distancing themselves from their employing organisation's goals. These distancing tactics include a stronger emphasis on belonging to other groupings whose values coincide more with their own established identities and are likely to be more stable than those of the organisation, and therefore reinforce and maintain such identities. Such 'alternative value systems' can be seen in the social support given by the cultures of the groups/teams to which workers belong, the reminder of past values, the development of instrumentalism in which an emphasis is placed on non-work identities, cynicism about management, and any situation in which difference is asserted, particularly difference from management.
Outflanking is also apparent in the various ways in which workers are able to restrict the impact of organisational rhetoric, such as through non-attendance at organisational meetings, and ignoring corporate communications. Distancing allows workers to protect themselves while appropriating their practice of science through taking ownership of their work, to receive the personal rewards and feedback from it that matches with their ideas about who they are, and the original meaning that work had for them, while ostensibly doing the work of the organisation. Workers use training to develop their science-based skills, and innovation and efficiency to make more time for science, not to save the organisation money, or to produce profitable products. (Such innovation is invisible to corporate management.) For others who are of a more instrumentalist nature, this method of compliance enables them to survive in employment while achieving their satisfaction and identity reinforcement elsewhere. The survival in work thus obtained is in itself resistance to the insecurity of estrangement.

\section{Compliance by Resisting Alienation}

I devised another model to describe how scientists resisted the experience of alienation from the product of their work (see Figure 7) by attempting to take control to make it most meaningful to them. This compliance was mainly achieved by using distancing techniques, which protected their sense of themselves as decent and honest workers, doing something for others, the environment, and science, by carrying out scientific work.

On some rare occasions, scientists seized opportunities to directly resist by not doing reports asked for by corporate unless told why and unless backing was received by a line manager or simply by not doing things asked unless asked several times. (Frequently there was never a follow-up request.)

Scientists were able to distance themselves from corporate goals by emphasising the values of the scientific community and by saying how the actions of corporate management look "silly" or "stupid" in their eyes. Scientists also played the funding game by perceiving it to be a competitive 'game' in which they take on the identity of 'player', not their 'real' selves. They hope these techniques will leave them 'free' to get on with their science. They are then able to appropriate the work, time and resources of their employer to do "more science" (not to sabotage, pilfer, steal or waste time not working, as most writing on resistance suggests). 


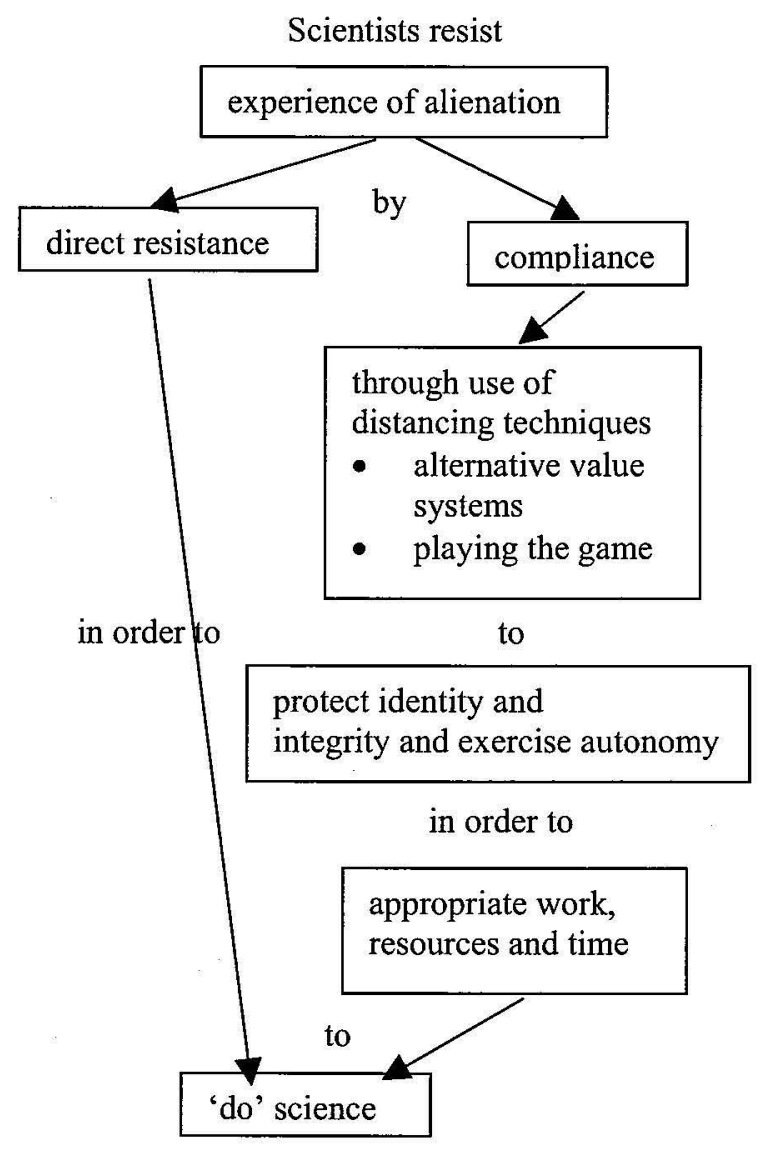

Figure 7: Model of how scientists try to resist alienation in a system of normative control

This can be illustrated in many ways. Time was appropriated when staff used the 'average day' entry facility when filling in their time sheets rather than keeping accurate records of the time spent on individual programmes. There was no absenteeism, however, scientists gave priority to conferences rather than commercial clients, scientific excellence rather than "just enough' techniques, and their hearts were in their science, or, as they became increasingly instrumental, in their nonwork activities, rather than in their loyalty to organisational goals. Science managers who were supposed to be managing contrived ways in which they could do science - by coming to work in the evenings or at weekends, or giving more management duties to others. New technologies and processes, and the contracting out of routine work enabled staff to do more science.

A great example of the symbolic appropriation of resources and time was contained in a phone conversation I was privy to, between a scientist, Walter, and a colleague on another YCo campus. It was about the launching of YCo's subsidiary company $\mathrm{XCo}$ that afternoon, which was to be celebrated simultaneously on all YCo campuses. Walter refers to corporate management as the 'police'. "You'll have the police there. No police here. We're going to use the free champagne to toast the future of science." The champagne, specially labelled to celebrate an organisational achievement, was to be appropriated for a radical purpose, to celebrate the future of science, hence resisting the appropriation of a science identity by the organisational senior management.

\section{Future Research}

As this paper reflects on the experiences of employees within one specific CRI it would be worth pursuing similar research within other contexts. What is it like for workers in other CRIs? What has been the impact on ordinary workers in other public sector organisations such as health and welfare, which underwent restructuring throughout the late 1980s? What are the future implications for a workforce which traditionally was based on a high level of commitment to public good and public service? Is this the way to implement Government policy?

\section{Conclusion}

I have argued that scientific staff resist and protect themselves from the experiences of estrangement and alienation by the use of distancing tactics which enabled them to appropriate resources and time in order to practise science and reinforce and maintain their identities. These processes have enabled them to be 'compliant' workers.

Achieving compliance by using the techniques I have described is not a 'happy ending' story. I was made powerfully aware of this one day when I was expounding my views to one of the members of a science group I had studied. Without consciousness of what he was doing he found the nearest wall and hit his head against it, and almost in tears, said, "But it is so stressful!" So, practising the distancing tactics I have described has not been successful for most staff. The fact is they are still unhappy.

The further you climb up the ladder The sadder you get and the madder ...

(Excerpt from limerick contest to celebrate YCo's tenth birthday, 17-7-02)

\section{References}

Ackroyd, S. and Thompson, P. (1999). Organizational Misbehaviour. London, Thousand Oaks, CA: Sage Publications.

ACRI (2002). Transforming New Zealand through Science: Concepts for a performance based science system. Off www.acri.cri.nz/views/statements.shtml. 
Ashforth, B.E., Mael, F.A. (1998). The Power of Resistance: Sustaining Valued Identities. In Kramer, R.M. and Neale, M.A. (eds) (1998). Power and Influence in Organizations. Thousand Oaks, CA: Sage Publications, 89-119.

Bauman, Z. (2001). Identity in the globalising world. Social Anthropology, 9(2): 121-129.

Casey, C. (1995). Work, Self and Society: After industrialism. London and New York: Routledge.

Clegg, S. (1994). Power Relations and the Constitution of the Resistant Subject. In Jermier, J.M., Knights, D. and Nord, W. (eds) (1994). Resistance and Power in Organizations. London and New York: Routledge, 274-325.

Clegg, S. (1990). Modern Organizations. London: Sage.

Clegg, S. (1989). Frameworks of Power. London: Sage.

Collinson, D. (1994). Strategies of Resistance: Power, knowledge and subjectivity in the workplace., In Jermier, J.M., Knights, D. and Nord, W. (eds) (1994). Resistance and Power in Organizations. London and New York: Routledge, 25-68.

Cohen, S. and Taylor, L. (1992, $2^{\text {nd }}$ Ed.). Escape Attempts: The Theory and Practice of Resistance to Everyday Life. London: Routledge.

Crozier, M. (1964). The bureaucratic phenomenon. Chicago: University of Chicago Press.

Edwards, R. (1979). Contested Terrain: The Transformation of the Workplace in the Twentieth Century. London: Heinemann.

Fox, M.F. (1995). Women and Scientific Careers. In Jasanoff, S., Markle, J.C., Peterson, J.C. and Pinch, T.J. (eds) !995). The Handbook of Science and Technology Studies. Thousand Oaks, CA: Sage Publications, 205-223.

Goffman, E. (1961). Role Distance. New York: Bobbs Merrill.

Gouldner, A.W. (1954). Patterns of Industrial Bureaucracy. New York: Free Press.

Harding, S. (ed.) (1992). The "Racial" Economy of Science: Toward a Democratic Future. Bloomington: Indiana University Press.

Hodgson, P. (2000). The Government's Vision for Science and Technology. Press Release, New Zealand Government 17/3/00: Institute of the Royal Society public lecture series, Hutton Theatre, Otago Museum, Dunedin.

Hodson, R. (1995). Worker Resistance: An Underdeveloped Concept in the Sociology of Work. Economic and Industrial Democracy, 16: 79-110.
Keller, E.F. (1995). The Origin, History, and Politics of the Subject Called "Gender and Science": A First Person Account. In Jasanoff, S., Markle, J.C., Peterson, J.C. and Pinch, T.J. (eds) (1995). The Handbook of Science and Technology Studies. Thousand Oaks, CA: Sage Publications, 80-94

Keller, E.F. (1990). Gender and Science. In Nielsen, J.McC. (ed.) (1990). Feminist Research Methods: Exemplary readings in the social sciences. Boulder, CO: Westview Press, 41-57.

Kelman, H.C. (1958). Compliance, identification and internalization: Three processes of attitude change. Journal of Conflict Resolution, 2: 51-60.

Kirkup, G. and Keller, L.S. (1992). Inventing Women: Science, Technology and Gender. Cambridge, U.K.: Polity Press.

Klein, D. $\left(1976,3^{\text {rd }}\right.$ ed.). Some Notes on the Dynamics of Resistance to Change: The Defender Role. In Bennis, W.G., Benne, K.D., Chin, R. and Corey, K.E. (eds) (1976, $3^{\text {rd }}$ ed.). The Planning of Change. New York: Holt, Rinehart and Winston, 117-124.

Knights, D. and Willmott, H. (1999). Management Lives: Power and Identity in Work Organizations. Thousand Oaks: Sage Publications.

Lancashire, J. (2002). Achieving Optimal Science. Presented at Primary Resources Forum, Preserving New Zealand's Wealth Generating Capacity, 26 June 2002, Massey University, Palmerston North.

Nichols, T. and Beynon, H. (1977). Living with Capitalism. London: Routledge and Kegan Paul.

Nord, W. and Jermier J.M. (1994). Overcoming resistance to resistance: Insights from a study of the shadows. Public Administration Quarterly, 17(4): 396-403.

Rose, M. (1978 [1975]). Industrial Behaviour: Theoretical Development Since Taylor. Middlesex, England: Penguin.

Rose, M. (1988, $2^{\text {nd }}$ ed.). Industrial Behaviour: Research and Control. London: Penguin.

Schiebinger, L. (1999). Has Feminism Changed Science? Cambridge, MA: Harvard University Press.

Simmel, G. (1971). Individuality and Social Forms. Chicago: University Press.

Smith, C., Knights, D. and Willmott, H. (eds) (1996[1991]). White-collar work: the non-manual labour process. Basingstoke: Macmillan.

Smith, C. and Thompson, P. (1999). Reevaluating the Labor Process Debate. In Wardell, M., Steiger, 
T.L. and Meiksins, P. (eds) (1999). Rethinking the Labor Process. Albany: State University of New York Press, 205-231.

Sprouse, M. (ed.) (1992). Sabotage in the American Workplace. San Francisco: Pressure Drop Press.

Tilly, C. (1978). From Mobilization to Revolution. Reading, MA: Addison-Wesley Publishing Company Inc.
Willmott, H. (1993). Strength is Ignorance; Slavery is Freedom: Managing Culture in Modern Organizations. Journal of Management Studies, 30(4): 515-552.

Zuckerman, H., Cole, J. and Bruer, J. T. (eds) (1991). The Outer Circle: Women in the Scientific Community. New York: Norton. 